ОРИГИНАЛНИ НАУЧНИ ЧЛАНЦИ

ОРИГИНАЛЬНЫЕ НАУЧНЫЕ СТАТЬИ

ORIGINAL SCIENTIFIC PAPERS

\title{
ANSARI'S METHOD IN GENERALIZATIONS OF SOME RESULTS IN THE FIXED POINT THEORY: SURVEY
}

\author{
Tatjana M. Došenovića ${ }^{\text {, Stojan N. Radenovićb }}$ \\ a University of Novi Sad, Faculty of Technology, \\ Novi Sad, Republic of Serbia, \\ e-mail: tatjanad@tf.uns.ac.rs, \\ ORCID ID: Dhttp://orcid.org/0000-0002-3236-4410 \\ b University of Belgrade, Faculty of Mechanical Engineering, \\ Belgrade, Republic of Serbia, \\ e-mail: radens@beotel.net, \\ ORCID ID: (Dhttp://orcid.org/0000-0001-8254-6688
}

http://dx.doi.org/10.5937/vojtehg66-16045

FIELD: Mathematics

ARTICLE TYPE: Original Scientific Paper ARTICLE LANGUAGE: English

Abstract:

The aim of this paper is to show that the C-class function introduced by A. H. Ansari is a powerful weapon for the generalization of many important results in the theory of fixed points.

Keywords: C class function, Metric space, Cauchy sequence, Common fixed point, Fixed point.

\section{Introduction}

With the advent of $S$. Banach paper (Banach, 1922), the development of the theory of fixed point is moved upwards. A huge number of scientists, for more than 90 years, have managed to generalize Banach contraction principle (Abbas \& Jungck, 2008, pp.416420), (Altun et al, 2010, pp.2238-2242), (Boyd \& Wong, 1969, pp.458464), (Đorić, 2009, 1896-1990), (Geraghty, 1973, pp.604-608), (Amini-Harandi \& Emami, 2010, pp.2238-2242), (Hussain et al, 2013),

ACKNOWLEDGMENT: The first author is grateful for the financial support from the Ministry of Education and Science and Technological Development of the Republic of Serbia (Matematički modeli nelinearnosti, neodređenosti i odlučivanja, 174009) and from the Provincial Secretariat for Higher Education and Scientific Research, Province of Vojvodina, Republic of Serbia, project no. 142-451-2838/2017-01. 
(Harjani \& Sadarangani, 2009, 3403-3410), (Jachymski, 2011, pp.768774), (Jungck, 1976, pp.261-263), (Karapinar \& Salimi, 2012), (Khan et al, 1984, pp.1-9), (Liu et al, 2015), (Rhoades, 1977, pp.257-290), (Rhoades, 2001, pp.2683-2693), (Radenović \& Kadelburg, 2010, pp.1776-1783), (Radenović et al, 2012, pp.625-645), (Salimi et al, 2013), (Samet et al, 2012, pp.2154-2165). In 2014 A. H. Ansari (Ansari, 2014a, pp.373-376), (Ansari, 2014b, pp.377-380) introduced the concept of $C$ class functions which cover a large class of contractive conditions, see also (Ansari, 2014a, pp.373-376), (Ansari, 2014b, pp.377-380), (Ansari et al, 2017, pp.2657-2673), (Ansari \& Chandok, 2016, pp.65-71).

Definition 1 (Ansari et al, 2017, pp.2657-2673) A $C$-class function is a continuous function $F:[0, \infty) \times[0, \infty) \rightarrow R$ such that for any $x, y \in[0, \infty)$, the following conditions hold:

(C1) $F(x, y) \leq x$

(C2) $F(x, y)=x$ implies that either $x=0$ or $y=0$.

An extra condition on $F$ that $F(0,0)=0$ could be imposed in some cases if required. By $\mathrm{C}$ we will denote the class of all $C$-functions.

Example 1 (Ansari et al, 2017, pp.2657-2673) The following functions belong to the class $\mathrm{C}$ :

1. $F(x, y)=x-y$.

2. $F(x, y)=m x$, for some $m \in(0,1)$.

3. $F(x, y)=\frac{x}{(1+y)^{r}}$ for some $r \in(0, \infty)$.

4. $F(x, y)=\frac{\log \left(y+a^{x}\right)}{1+y}$, for some $a>1$.

5. $F(x, y)=(x+l)^{\left(1 /(1+y)^{r}\right)}-l, l>1$, for $r \in(0, \infty)$.

6. $F(x, y)=x-\frac{y}{k+y}$.

7. $F(x, y)=x-\varphi(x)$, where $\varphi:[0, \infty) \rightarrow[0, \infty)$ is a continuous function such that $\varphi(t)=0$ if and only if $t=0$.

8. $F(x, y)=\sqrt[n]{\ln \left(1+x^{n}\right)}$.

We start this section with the following definitions and notions: 
Definition 2 (Ansari, 2014b, pp.377-380) A mapping $F:[0,+\infty)^{2} \rightarrow R$ has a property $C_{F}$, if there exists an $C_{F} \geq 0$ such that

$\left(C_{F} 1\right) F(x, y)>C_{F}$ implies $x>y$;

$\left(C_{F} 2\right) F(y, y) \leq C_{F}$, for all $y \in[0,+\infty)$.

For more examples of $C$-class functions that have the property $C_{F}$ see (Ansari, 2014b, pp.377-380) Here we announce the following three examples

a) $F(x, y)=x-y, C_{F}=r, r \in[0,+\infty)$;

b) $F(x, y)=x-\frac{(2+y) y}{1+y}, C_{F}=0$;

c) $F(x, y)=\frac{x}{1+k y}, k \geq 1, C_{F}=\frac{r}{1+k}, r \geq 2$.

Let $\Psi$ denote the class of all functions $\psi:[0, \infty) \rightarrow[0, \infty), \Phi$ denote the class of all functions $\phi:[0, \infty) \rightarrow[0, \infty)$ and $F$ elements of $C$ satisfying the following conditions:

(i) $\psi$ is non-decreasing and continuous;

(ii) $\phi$ is non-decreasing and continuous;

(iii) $\psi(t)-F(\psi(s), \phi(s))>0$ for all $t>0$ and $s=t$ or $s=0$.

The condition (iii) generalizes (2.3) from (Karapinar \& Salimi, 2012, p.9).

Definition 3 (Ansari et al, 2017, pp.2657-2673) A subclass of type $I$ is a function $H: R \times[0, \infty) \rightarrow R$ if it is continuous and

$s \geq 1$ implies $H(1, t) \leq H(s, t)$ for all $t \in[0, \infty)$.

Example 2 (Ansari et al, 2017, pp.2657-2673) We have the following functions of the subclass of the type $I$ :

- $H(s, t)=(t+l)^{s}, l>1$,

- $H(s, t)=(s+l)^{t}, l>1$,

- $H(s, t)=s t^{n}, n \in N$, 
- $H(s, t)=s t$,

- $H(s, t)=t$,

- $H(s, t)=\frac{s+1}{2} t$,

- $H(s, t)=\frac{2 s+1}{3} t$,

- $H(s, t)=\left(\frac{\sum_{i=0}^{n} s^{n-i}}{n+1}\right) t$,

- $H(s, t)=\left(\frac{\sum_{i=0}^{n} s^{n-i}}{n+1}+l\right)^{t}, l>1$.

Definition 4 (Ansari et al, 2017, pp.2657-2673) We say that the pair $(F, H)$ is an upclass of the type $I$ if $F:[0, \infty) \times[0, \infty) \rightarrow R$ is continuous, $H$ is a function of the subclass of the type $I$ and satisfies:

(1) $0 \leq x \leq 1$ implies $F(x, y) \leq F(1, y)$

(2) $H\left(1, y_{1}\right) \leq F\left(x, y_{2}\right)$ implies $y_{1} \leq x y_{2}$, for all $x, y, y_{1}, y_{2} \in[0, \infty)$.

Example 3 (Ansari et al, 2017, pp.2657-2673) Below are listed the functions of the upclass of the type $I$, for all $s \in R, t, y \in[0, \infty)$, $x \in[0,1]:$

- $H(s, t)=(t+l)^{s}, l>1, F(x, y)=x y+l$,

- $H(s, t)=(t+l)^{s}, l>1, F(x, y)=(1+l)^{x y}$,

- $H(s, t)=s t^{n}, F(x, y)=x^{n} y^{n}$

- $H(s, t)=s t, F(x, y)=x y$. 
Definition 5 (Ansari et al, 2017, pp.2657-2673) We say that the pair $(F, H)$ is a special upclass of the type $I$ if $F:[0, \infty) \times[0, \infty) \rightarrow R$ is continuous, $H$ is a function of the subclass of the type $I$ and satisfies:

(1) $0 \leq x \leq 1$ implies $F(x, y) \leq F(1, y)$

(2) $H(1, t) \leq F(1, y)$ implies $t \leq y$, for all $y, t \in[0, \infty)$.

Example 4 (Ansari et al, 2017, pp.2657-2673) The following functions are a special upclass of the type $I$, for all $s \in R, t, x, y \in[0, \infty)$ :

- $H(s, t)=\left(t^{k}+l\right)^{s^{n}}, l>1, F(x, y)=x^{m} y^{k}+l$,

- $H(s, t)=\left(s^{n}+l\right)^{t^{k}}, l>1, F(x, y)=(1+l)^{x^{m} y^{k}}$,

- $H(s, t)=s^{n} t^{k}, F(x, y)=x^{p} y^{k}$,

- $H(s, t)=s t, F(x, y)=x y$.

Remark 1 (Ansari et al, 2017, pp.2657-2673) Every pair $(F, H)$ of the upclass of the type $I$ also belongs to the class of a special upclass of the type $I$, but converse is not true.

Assertions similar to the following lemma were used (and proved) in the course of proofs of several fixed point results in various papers (Radenović et al, 2012, pp.625-645).

Lemma 1 (Radenović et al, 2012, pp.625-645) Let $(X, d)$ be a metric space and let $\left\{x_{n}\right\}$ be a sequence in $X$ such that

$$
\lim _{n \rightarrow \infty} d\left(x_{n}, x_{n+1}\right)=0 \text {. }
$$

If $\left\{x_{n}\right\}$ is not a Cauchy sequence, then there exist $\varepsilon>0$ and two sequences $\left\{m_{k}\right\}$ and $\left\{n_{k}\right\}$ of positive integers such that $n_{k}>m_{k}>k$ and the following sequences tend to $\varepsilon^{+}$when $k \rightarrow \infty$ :

$$
d\left(x_{m_{k}}, x_{n_{k}}\right), d\left(x_{m_{k}}, x_{n_{k}+1}\right) d\left(x_{m_{k}-1}, x_{n_{k}}\right), d\left(x_{m_{k}-1}, x_{n_{k}+1}\right) .
$$


Definition 6 (Abbas \& Jungck, 2008, pp.416-420) Let $f$ and $g$ be self maps of a set $X$. If $\omega=f x=g x$ for some $x \in X$, then $x$ is called a coincidence point of $f$ and $g$, and $\omega$ is called a point of coincidence of $f$ and $g$. The pair $f, g$ of self maps is weakly compatible if they commute at their coincidence points.

Proposition 1 (Abbas \& Jungck, 2008, pp.416-420) Let $f$ and $g$ be weakly compatible self maps of a set $X$. If $f$ and $g$ have a unique point of coincidence $\omega=f x=g x$, then $\omega$ is the unique common fixed point of $f$ and $g$.

\section{Main results}

Previously described functions attracted the attention of authors and now there are various generalizations of the results from the fixed point theory, not only in a metric space, but also in the partial metric spaces, metric like-spaces, G-metric spaces,...(Ansari, 2014a, pp.373-376), (Ansari, 2014b, pp.377-380), (Ansari et al, 2017, pp.2657-2673), (Isik et al, 2015, pp.703-708), (Ansari \& Chandok, 2016, pp.65-71). In this paper, we will present some of these results. Also, we shall prove some new results, which generalize already known ones, by using the $C$-class functions introduced recently by A.H. Ansari (Ansari, 2014a, pp.373-376), (Ansari, 2014b, pp.377-380). In this review paper, we will use only $C$ class functions.

Our first (probably new) result is the following:

Theorem 1 Let $(X, d)$ be a complete metric space. Suppose that the mappings $f, g: X \rightarrow X$ satisfy the following condition

$$
\psi(d(f x, f y)) \leq F(\psi(d(g x, g y)), \phi(d(g x, g y)))
$$

for all $x, y \in X$ where $\psi \in \Psi, \varphi \in \Phi$ and $F \in C$. If the range of $g$ contains the range of $f$ and $f(X)$ or $g(X)$ is a closed subset of $X$, then $f$ and $g$ have a unique point of coincidence in $X$. Moreover, if $f$ and $g$ are weakly compatible, then $f$ and $g$ have a unique common fixed point. 
Remark 2 Putting in (1): $\psi(t)=t, \phi(t)=(1-k) t, k \in(0,1)$ and $F(s, t)=s-t$ for all $s, t \in[0, \infty)$ we get a well-known Jungck's result from (Jungck, 1976, pp.261-263). Hence, Theorem 1 is a genuine generalization of the old and important Jungck's result in several directions (see all assumptions in (Jungck, 1976, pp.261-263).

Further, putting in (1): $\psi(t)=t, F(s, t)=\beta(s) \cdot s$ for all $s, t \in[0, \infty)$ where $\beta:[0, \infty) \rightarrow[0,1)$ such that $t_{n} \rightarrow 0^{+}$whether $\beta\left(t_{n}\right) \rightarrow 1^{-}, g=I_{X}$ (identity mapping on $X$ ), we get a well-known Geraghty type result (Geraghty, 1973, pp.604-608). Hence, Theorem 1 is a new generalization of this old and important result in the fixed point theory in the framework of complete metric spaces.

Proof. Let us prove that the point of coincidence of $f$ and $g$ is unique in the case that it exists. Suppose that $\omega$ and $\delta$ are two distinct points of coincidence of $f$ and $g$. From this follows that there exist two points $u_{\omega}$ and $u_{\delta}$ such that $f u_{\omega}=g u_{\omega}=\omega \neq \delta=f u_{\delta}=g u_{\delta}$. Now, (1) implies

$$
\begin{gathered}
\psi(d(\omega, \delta))=\psi\left(d\left(f u_{\omega}, f u_{\delta}\right)\right) \\
\leq F\left(\psi\left(d\left(g u_{\omega}, g u_{\delta}\right)\right), \phi\left(d\left(g u_{\omega}, g u_{\delta}\right)\right)\right) \\
=F(\psi(d(\omega, \delta)), \phi(d(\omega, \delta))) \leq \psi(d(\omega, \delta)),
\end{gathered}
$$

that is

$$
F(\psi(d(\omega, \delta)), \phi(d(\omega, \delta)))=\psi(d(\omega, \delta)) .
$$

From (2) according to the property of the function $F$ follows that either $\psi(d(\omega, \delta))=0$ or $\phi(d(\omega, \delta))=0$. In both cases, we get a contradiction.

Further, let $x_{0}$ be an arbitrary point in $X$. Let us choose a point $x_{1} \in X$ such that $y_{0}=f x_{0}=g x_{1}$. This can be done, since the range of $g$ contains the range of $f$. Continuing this process, having chosen $x_{n}$ in $X$, we obtain $x_{n+1}$ in $X$ such that $y_{n}=f x_{n}=g x_{n+1}$. Now consider the following two possible cases:

$1^{0} y_{k}=y_{k+1}$ for some $k \in N$. Hence, $g x_{k+1}=f x_{k+1}$ is a (unique) point of coincidence and then the proof of Theorem 1 is finished. 
$2^{0}$ Thus, suppose that $y_{n} \neq y_{n+1}$ for all $n \in N \cup\{0\}$. In this case, we have

$$
\begin{gathered}
\psi\left(d\left(y_{n+1}, y_{n+2}\right)\right)=\psi\left(d\left(f x_{n+1}, f x_{n+2}\right)\right) \\
\leq F\left(\psi\left(d\left(g x_{n+1}, g x_{n+2}\right)\right), \phi\left(d\left(g x_{n+1}, g x_{n+2}\right)\right)\right) \\
=F\left(\psi\left(d\left(y_{n}, y_{n+1}\right)\right), \phi\left(d\left(y_{n}, y_{n+1}\right)\right)\right) \\
\leq \psi\left(d\left(y_{n}, y_{n+1}\right)\right) .
\end{gathered}
$$

Since $\quad \psi \in \Psi$ we get that $d\left(y_{n+1}, y_{n+2}\right) \leq d\left(y_{n}, y_{n+1}\right)$, i.e., $d\left(y_{n}, y_{n+1}\right) \downarrow, r \geq 0$. We prove now that $r=0$. Indeed, if $r>0$, then passing to the limit in the previous relation when $n \rightarrow \infty$, we obtain that

$$
\psi(r) \leq F(\psi(r), \phi(r)) \leq \psi(r),
$$

that is $F(\psi(r), \phi(r))=\psi(r)$. This implies that either $\psi(r)=0$ or $\phi(r)=0$. In both cases we get a contradiction. Hence, $\lim _{n \rightarrow \infty} d\left(y_{n}, y_{n+1}\right)=0$.

We next prove that $\left\{y_{n}\right\}$ is a Cauchy sequence in a complete metric space $(X, d)$. If that is not case, then by using Lemma 1 we get that there exist $\varepsilon>0$ and two sequences $\left\{m_{k}\right\}$ and $\left\{n_{k}\right\}$ of positive integers and sequences

$$
d\left(y_{m_{k}} y_{n_{k}}\right), d\left(y_{m_{k}} y_{n_{k}+1}\right), d\left(y_{m_{k}-1} y_{n_{k}}\right), d\left(y_{m_{k}-1} y_{n_{k}+1}\right),
$$

all tend to $\varepsilon^{+}$when $k \rightarrow \infty$. By applying condition (1) to the elements $x=x_{m_{k}}$ and $y=x_{n_{k}+1}$ and since $y_{n}=f x_{n}=g x_{n+1}$ for each $n \geq 0$, we get that

$$
\psi\left(d\left(y_{m_{k}} y_{n_{k}+1}\right)\right) \leq F\left(\psi\left(d\left(y_{m_{k-1}} y_{n_{k}}\right)\right) \phi \phi\left(d\left(y_{m_{k}-1} y_{n_{k}}\right)\right)\right) .
$$

Letting $k \rightarrow \infty$ in (3), we obtain

$$
\psi(\varepsilon) \leq F(\psi(\varepsilon), \phi(\varepsilon)),
$$

which is a contradiction because $\varepsilon>0$. This shows that $\left\{y_{n}\right\}=\left\{f x_{n}\right\}=\left\{g x_{n+1}\right\}$ is a Cauchy sequence in a complete metric space $(X, d)$.

Since $g(X)$ is closed in a complete metric space $(X, d)$, then it is a complete metric space. Therefore, there exists $u, v \in X$ such that $v=g u$ 
and $\lim _{n \rightarrow \infty} g x_{n}=g u=v$. We shall show that also $f u=v=g u$. Indeed, putting $x=x_{n}, y=u$ in (1) we get

$$
\psi\left(d\left(f x_{n}, f u\right)\right) \leq F\left(\psi\left(d\left(g x_{n}, g u\right)\right), \phi\left(d\left(g x_{n}, g u\right)\right)\right) .
$$

Letting $n \rightarrow \infty$ in (4) and applying the properties of all three functions $F, \psi$ and $\phi$, we get

$$
\psi(d(g u, f u)) \leq F(\psi(d(g u, g u)), \phi(d(g u, g u))) \leq \psi(d(g u, g u))=\psi(0)=0,
$$

i.e., $f u=g u$ is a (unique) point of coincidence of the functions $f$ and $g$.

By the Proposition $1 f$ and $g$ have the unique common fixed point.

In the case when $f(X)$ is a closed subset in $(X, d)$, the proof is similar.

Putting $\psi(t)=\phi(t)=t, F(s, t)=\frac{s^{2} t}{1+s t}, g=I_{X}$ the identity mapping of $X$ in Theorem 1, we get the following result:

Corollary 1 Let $(X, d)$ be a complete metric space. Suppose mappings $f: X \rightarrow X$ satisfies

$$
d(f x, f y) \leq \frac{d^{3}(x, y)}{1+d^{2}(x, y)}
$$

for all $x, y \in X$. Then $f$ has a unique fixed point in $X$.

Putting $\psi(t)=\phi(t)=t, F(s, t)=\varphi(s)$, where $\varphi:[0, \infty) \rightarrow[0, \infty)$ is upper semicontinuous from the right, satisfying $\varphi(t)<t$ for $t>0$ as well as $\varphi(0)=0, g=I_{X}$ the identity mapping of $X$ in Theorem 1 we get the following well-known Boyd and Wong result (Boyd \& Wong, 1969, pp.458-464).

Corollary 2 Let $(X, d)$ be a complete metric space. Suppose that a mapping $f: X \rightarrow X$ satisfies the following condition

$$
d(f x, f y) \leq \varphi(d(x, y))
$$

for all $x, y \in X$. Then $f$ has a unique fixed point, say $u \in X$ and $f^{n} x \rightarrow u$ as $n \rightarrow \infty$ for each $x \in X$. 
Putting $\psi(t)=\phi(t)=t, F(s, t)=s-\varphi(s)$, where $\varphi:[0, \infty) \rightarrow[0, \infty)$ is a continuous function such that $\varphi(t)=0$ if and only if $t=0, g=I_{X}$ the identity mapping of $X$ in Theorem 1 we get the following well-known B.E. Rhoades result (Rhoades, 2001, pp.2683-2693).

Corollary 3 Let $(X, d)$ be a complete metric space. Suppose that the mappings $f: X \rightarrow X$ satisfies the following condition

$$
d(f x, f y) \leq d(x, y)-\varphi(d(x, y))
$$

for all $x, y \in X$. Then $f$ has a unique fixed point, say $u \in X$ and $f^{n} x \rightarrow u$ as $n \rightarrow \infty$ for each $x \in X$.

In the sequel of this section we shall consider two results which provide the existence of a coincidence point and a common fixed point for three mappings satisfying the generalized $(F, \psi, \phi)$-contractive condition. These results are addressed in the following theorems.

Theorem 2 Let $(X, d)$ be a metric space, and let $f, g, S: X \rightarrow X$ be three mappings such that for all $x, y \in X$

$$
\psi(d(f x, g y)) \leq F\left(\psi(m(x, y)), \phi\left(m_{1}(x, y)\right)\right),
$$

for some $\psi \in \Psi, \phi \in \Phi$ and $F \in \mathrm{C}$, where

$$
m(x, y)=\max \left\{d(S x, S y), d(S x, f x), d(S y, g y), \frac{1}{2}(d(S x, g y)+d(S y, f x))\right\}
$$

and

$$
m_{1}(x, y)=\max \{d(S x, S y), d(f x, S x), d(g y, S y)\} .
$$

If $f X \cup g X \subset S X$ and $S(X)$ is a complete subspace of $(X, d)$, then $f, g$ and $S$ have a unique point of coincidence. Moreover, if $(f, S)$ and $(g, S)$ are weakly compatible, then $f, g$ and $S$ have a unique common fixed point.

The proof of the following theorem is similar to that of Theorem 1.

Theorem 3 Let $(X, d)$ be a complete metric space, and let $f, g, S: X \rightarrow X$ be three mappings such that for all $x, y \in X$ 


$$
\psi(d(f x, g y)) \leq F\left(\psi(m(x, y)), \phi\left(m_{1}(x, y)\right)\right),
$$

for some $\psi \in \Psi, \phi \in \Phi$ and $F \in \mathrm{C}$, where

$$
\begin{gathered}
m(x, y)=\max \left\{d(S x, S y), \frac{1}{2}(d(S x, f x)+d(S y, g y)), \frac{1}{2}(d(S x, g y)+d(S y, f x))\right\} \\
\text { and } \\
m_{1}(x, y)=\max \{d(S x, S y), d(f x, S x), d(g y, S y)\} . \\
\text { If } f X \cup g X \subset S X \text { and } S(X) \text { is a complete subspace of }(X, d),
\end{gathered}
$$
then $f, g$ and $S$ have a unique point of coincidence. Moreover, if $(f, S)$ and $(g, S)$ are weakly compatible, then $f, g$ and $S$ have a unique common fixed point.

The following results represent one other version of Altun Theorem (Altun et al, 2010, pp.310-316) in the terms of $(F, \psi, \phi)$-contractive mappings.

Theorem 4 Let $(X, d)$ be a complete metric space, and let $f, g: X \rightarrow X$ be two mappings such that for some $\psi \in \Psi, \phi \in \Phi$ and $F \in \mathrm{C}$ and for all $x, y \in X$ there exists

$$
u(x, y) \in\left\{d(x, y), d(x, f x), d(y, g y), \frac{1}{2}(d(x, g y)+d(y, f x))\right\}
$$

such that

$$
\psi(d(f x, g y)) \leq F(\psi(u(x, y)), \phi(u(x, y))),
$$

then $f$ and $g$ have a unique fixed point.

Let $(X, \preccurlyeq)$ be a partially ordered set. A pair $(f, g)$ of self-maps of $X$ is said to be weakly increasing if $f x \leqslant g f x$ and $g x \leqslant f g x$ for all $x \in X$. There are examples (see Altun et al, 2010, pp.310-316) when neither of such mappings $f, g$ is nondecreasing w.r.t $\leqslant$ In particular the pair $\left(f, i_{X}\right), \quad\left(i_{X}\right.$ is the identity mapping on $\left.X\right)$ is weakly increasing if and only if $x \preccurlyeq f x$ for each $x \in X$.

Theorem 5 Let $(X, \preccurlyeq)$ be a partially ordered set and let there exist a metric $d$ on $X$ such that $(X, d)$ is a complete metric space. Let $(f, g)$ 
be a weakly increasing pair of self-maps on $X$. Suppose that there exists $\psi \in \Psi, \varphi \in \Phi$ and $F \in \mathrm{C}$ such that for every two comparable elements $x, y \in X$,

$$
\psi(d(f x, g y)) \leq F(\psi(M(x, y)), \phi(M(x, y))),
$$

where

$$
M(x, y)=\max \left\{d(x, y), d(x, f x), d(y, g y), \frac{1}{2}(d(x, g y)+d(y, f x))\right\} .
$$

Then in each of the following two cases the mappings $f$ and $g$ have at least one common fixed point:

(i) $f$ or $g$ is continuous, or

(ii) if a nondecreasing sequence $\left\{x_{n}\right\}$ converges to $x \in X$, then $\mathrm{x}_{\mathrm{n}} \preccurlyeq \mathrm{x}$ for all $n$.

Proof. Using that the pair of functions $(f, g)$ is weakly increasing, we can construct inductively, starting with an arbitrary $x_{0} \in X$, a sequence $\left\{x_{n}\right\}$ such that $x_{n} \preccurlyeq x_{n+1}$. Namely, denote:

$$
\begin{aligned}
& x_{1}=f x_{0} \preccurlyeq g f x_{0}=g x_{1}, \\
& x_{2}=g x_{1} \preccurlyeq f g x_{1}=f x_{2}, \\
& x_{3}=f x_{2} \preccurlyeq g f x_{2}=g x_{3},
\end{aligned}
$$

and in general, $x_{2 n+1}=f x_{2 n}$ and $x_{2 n+2}=g x_{2 n+1}$.

Suppose first that $x_{k}=x_{k+1}$ for some $k$. Then, the sequence $\left\{x_{n}\right\}$ is constant for $n \geq k$. Indeed, let $k=2 m$. Then $x_{2 m}=x_{2 m+1}$ and we obtain from (11) that

$$
\begin{aligned}
& \psi\left(d\left(x_{2 m+1}, x_{2 m+2}\right)\right)=\psi\left(d\left(f x_{2 m}, g x_{2 m+1}\right)\right) \leq \\
& \leq F\left(\psi\left(M\left(x_{2 m}, x_{2 m+1}\right)\right), \phi\left(M\left(x_{2 m}, x_{2 m+1}\right)\right)\right),
\end{aligned}
$$

where

$$
\begin{gathered}
M\left(x_{2 m}, x_{2 m+1}\right)= \\
\max \left\{d\left(x_{2 m}, x_{2 m+1}\right), d\left(x_{2 m}, f x_{2 m}\right), d\left(x_{2 m+1}, g x_{2 m+1}\right),\right. \\
\left.\frac{1}{2}\left(d\left(x_{2 m}, g x_{2 m+1}\right)+d\left(x_{2 m+1}, f x_{2 m}\right)\right)\right\}
\end{gathered}
$$




$$
\begin{gathered}
=\max \left\{0,0, d\left(x_{2 m+1}, x_{2 m+2}\right), \frac{1}{2}\left(d\left(x_{2 m}, x_{2 m+2}\right)+0\right)\right\} \\
=\max \left\{d\left(x_{2 m+1}, x_{2 m+2}\right), \frac{1}{2}\left(d\left(x_{2 m}, x_{2 m+2}\right)+0\right)\right\} \\
=d\left(x_{2 m+1}, x_{2 m+2}\right) .
\end{gathered}
$$

Now further from (12) we get that

$\psi\left(d\left(x_{2 m+1}, x_{2 m+2}\right)\right) \leq F\left(\psi\left(d\left(x_{2 m+1}, x_{2 m+2}\right)\right), \phi\left(d\left(x_{2 m+1}, x_{2 m+2}\right)\right)\right) \leq \psi\left(d\left(x_{2 m+1}, x_{2 m+2}\right)\right)$, that is,

$$
\psi\left(d\left(x_{2 m+1}, x_{2 m+2}\right)\right)=F\left(\psi\left(d\left(x_{2 m+1}, x_{2 m+2}\right)\right), \phi\left(d\left(x_{2 m+1}, x_{2 m+2}\right)\right)\right),
$$

or equivalently either $\psi\left(d\left(x_{2 m+1}, x_{2 m+2}\right)\right)=0$ or $\phi\left(d\left(x_{2 m+1}, x_{2 m+2}\right)\right)=0$, i.e., $d\left(x_{2 m+1}, x_{2 m+2}\right)=0$. Hence, if $x_{k}=x_{k+1}, k=2 m$ we obtain that $x_{k+1}=x_{k+2}$. Similarly, if $k=2 m+1$, one easily obtains that $x_{k+1}=x_{k+2}$, and so the sequence $\left\{x_{n}\right\}$ is constant (starting from some $k$ ) and $x_{k}$ is a common fixed point of $f$ and $g$.

Suppose now that $x_{n} \neq x_{n+1}$ for each $n$. We shall prove that $d\left(x_{n}, x_{n+1}\right) \rightarrow 0$ as $n \rightarrow \infty$. Using condition (11) (which is possible since $x_{n}$ and $x_{n+1}$ are comparable for all $n$ ), we obtain

$$
\begin{gathered}
\psi\left(d\left(x_{2 n+2}, x_{2 n+1}\right)\right)=\psi\left(d\left(g x_{2 n+1}, f x_{2 n}\right)\right) \\
=\psi\left(d\left(f x_{2 n}, g x_{2 n+1}\right)\right) \leq F\left(\psi\left(M\left(x_{2 n}, x_{2 n+1}\right)\right), \phi\left(M\left(x_{2 n}, x_{2 n+1}\right)\right)\right),
\end{gathered}
$$

where

$$
\begin{gathered}
M\left(x_{2 n}, x_{2 n+1}\right)=\max \left\{d\left(x_{2 n}, x_{2 n+1}\right), d\left(x_{2 n}, f x_{2 n}\right), d\left(x_{2 n+1}, g x_{2 n+1}\right),\right. \\
\left.\frac{1}{2}\left(d\left(x_{2 n}, g x_{2 n+1}\right)+d\left(x_{2 n+1}, f x_{2 n}\right)\right)\right\} \\
=\max \left\{d\left(x_{2 n}, x_{2 n+1}\right), d\left(x_{2 n}, x_{2 n+1}\right), d\left(x_{2 n+1}, x_{2 n+2}\right), \frac{1}{2} d\left(x_{2 n}, x_{2 n+2}\right)\right\} \\
\leq \max \left\{d\left(x_{2 n}, x_{2 n+1}\right), d\left(x_{2 n+1}, x_{2 n+2}\right), \frac{1}{2}\left(d\left(x_{2 n}, x_{2 n+1}\right)+d\left(x_{2 n+1}, x_{2 n+2}\right)\right)\right\} \\
=\max \left\{d\left(x_{2 n}, x_{2 n+1}\right), d\left(x_{2 n+1}, x_{2 n+2}\right)\right\} .
\end{gathered}
$$


If $d\left(x_{2 n+1}, x_{2 n+2}\right) \geq d\left(x_{2 n}, x_{2 n+1}\right)>0$, then it follows

$\psi\left(d\left(x_{2 n+2}, x_{2 n+1}\right)\right) \leq F\left(\psi\left(d\left(x_{2 n+1}, x_{2 n+2}\right)\right), \phi\left(d\left(x_{2 n+1}, x_{2 n+2}\right)\right)\right) \leq \psi\left(d\left(x_{2 n+1}, x_{2 n+2}\right)\right)$, or equivalently, either $\psi\left(d\left(x_{2 m+1}, x_{2 m+2}\right)\right)=0$ or $\phi\left(d\left(x_{2 m+1}, x_{2 m+2}\right)\right)=0$.

This is a contradiction, because $d\left(x_{2 n+1}, x_{2 n+2}\right)>0$. Hence, $M\left(x_{2 n}, x_{2 n+1}\right)=d\left(x_{2 n}, x_{2 n+1}\right)$. Now, we further easily get that $d\left(x_{n+1}, x_{n+2}\right) \leq d\left(x_{n}, x_{n+1}\right)$ for all $n \in N \cup\{0\}$. This means that $d\left(x_{n}, x_{n+1}\right) \downarrow \quad r \geq 0$ as $n \rightarrow \infty$. Let $r>0$. Passing to the limit in the last inequality, when $n \rightarrow \infty$, we get

$$
\psi(r) \leq F(\psi(r), \phi(r)) \leq \psi(r),
$$

i.e., $F(\psi(r), \phi(r))=\psi(r)$, or equivalently, either $\psi(r)=0$ or $\phi(r)=0$. A contradiction. Hence, $d\left(x_{n}, x_{n+1}\right) \rightarrow 0$ as $n \rightarrow \infty$.

In order to prove that $\left\{x_{n}\right\}$ is a Cauchy sequence in $(X, d)$ we shall use the ideas from (Radenović et al, 2012, pp.625-645).

It is enough to prove that $\left\{x_{2 n}\right\}$ is a Cauchy sequence. Suppose the contrary. Then, for some $\varepsilon>0$ there exist subsequences $\left\{x_{2 m(k)}\right\}$ and $\left\{x_{2 n(k)}\right\}$ of $\left\{x_{2 n}\right\}$ such that $n(k)$ is the smallest index satisfying $n(k)>m(k)>k$ and $d\left(x_{m(k)}, x_{n(k)}\right) \geq \varepsilon$. In particular, $d\left(x_{m(k)}, x_{n(k)-2}\right)<\varepsilon$. Now, using Lemma 1 and putting in (11) $x=x_{2 n(k)}, y=x_{2 m(k)-1}(x$ and $y$ are obviously comparable) we have

$$
\begin{aligned}
& \psi\left(d\left(x_{2 n(k)+1,}, x_{2 m(k)}\right)\right)=\psi\left(d\left(f x_{2 n(k)}, g x_{2 m(k)-1}\right)\right) \leq \\
& \leq F\left(\psi\left(M\left(x_{2 n(k)}, x_{2 m(k)-1}\right)\right), \phi\left(M\left(x_{2 n(k)}, x_{2 m(k)-1}\right)\right)\right),
\end{aligned}
$$

where

$$
\begin{gathered}
M\left(x_{2 n(k)}, x_{2 m(k)-1}\right) \\
=\max \left\{d\left(x_{2 n(k)}, x_{2 m(k)-1}\right), d\left(x_{2 n(k)}, f x_{2 n(k)}\right), d\left(x_{2 m(k)-1}, g x_{2 m(k)-1}\right),\right. \\
\left.\quad \frac{1}{2}\left(d\left(x_{2 n(k)}, g x_{2 m(k)-1}\right)+d\left(x_{2 m(k)-1}, f x_{2 n(k)}\right)\right)\right\} \\
=\max \left\{d\left(x_{2 n(k)}, x_{2 m(k)-1}\right), d\left(x_{2 n(k)}, x_{2 n(k)+1}\right), d\left(x_{2 m(k)-1}, x_{2 m(k)}\right),\right.
\end{gathered}
$$




$$
\begin{gathered}
\left.\frac{1}{2}\left(d\left(x_{2 n(k)}, x_{2 m(k)}\right)+d\left(x_{2 m(k)-1}, x_{2 n(k)+1}\right)\right)\right\} \\
\rightarrow \max \left\{\varepsilon, 0,0, \frac{1}{2}(\varepsilon+\varepsilon)\right\}=\varepsilon .
\end{gathered}
$$

Passing to the limit in (13) when $k \rightarrow \infty$, we obtain that

$$
\psi(\varepsilon) \leq F(\psi(\varepsilon), \phi(\varepsilon)) \leq \psi(\varepsilon),
$$

that is $\varepsilon=0$, which is a contradiction. Hence, the sequence $\left\{x_{n}\right\}$ is a Cauchy sequence. Since $(X, d)$ is a complete metric space it follows that $x_{n} \rightarrow u$ for some element $u \in X$.

(i) Suppose that the mapping $g$ is continuous. Since $x_{2 n+1} \rightarrow u$, we obtain that $x_{2 n+2}=g x_{2 n+1} \rightarrow g u$. On the other hand, $x_{2 n+2} \rightarrow u$ (as a subsequence of $\left\{x_{n}\right\}$ ). It follows that $g u=u$. To prove that $f u=u$, using $u \preccurlyeq u$ we can put $x=y=u$ in (11) and obtain that

$$
\psi(d(f u, g u)) \leq F(\psi(M(u, u)), \phi(M(u, u)))=F(\psi(d(u, f u)), \phi(d(u, f u))),
$$

because $M(u, u)=d(u, f u)$. We further have,

$$
\psi(d(f u, u)) \leq F(\psi(d(u, f u)), \phi(d(u, f u))),
$$

from which follows (as in the previously cases) that $u=f u$.

The proof is similar if $f$ is continuous.

(ii) Suppose now that the condition (ii) of the theorem holds. The sequence $\left\{x_{n}\right\}$ is nondecreasing w.r.t $\preccurlyeq$ and it follows that $x_{n} \preccurlyeq u$. Take $x=x_{2 n}$, and $y=u$ (which are comparable) in (11) to obtain that

$$
\psi\left(d\left(f x_{2 n}, g u\right)\right) \leq F\left(\psi\left(M\left(x_{2 n}, u\right)\right), \phi\left(M\left(x_{2 n}, u\right)\right)\right) \text {, }
$$

where

$$
\begin{aligned}
& M\left(x_{2 n}, u\right)=\max \left\{d\left(x_{2 n}, u\right), d\left(x_{2 n}, f x_{2 n}\right), d(u, g u), \frac{1}{2}\left(d\left(x_{2 n}, g u\right)+d\left(u, f x_{2 n}\right)\right)\right\} \\
& \rightarrow \max \left\{0,0, d(u, g u), \frac{1}{2} d(u, g u)\right\}=d(u, g u) .
\end{aligned}
$$

Hence, we further obtain

$$
\psi\left(d\left(f x_{2 n}, g u\right)\right) \leq F(\psi(d(u, g u)), \phi(d(u, g u))),
$$


or passing to the limit, we get

$$
\psi(d(u, g u)) \leq F(\psi(d(u, g u)), \phi(d(u, g u))) .
$$

From the last relation we get that $g u=u$.

The fact that $u=f u$ is now derived in the same way as in the case (i). The theorem is proved.

Finally, we address the following definitions as well as maybe a new result.

Consider the following classes of functions from $[0, \infty)$ into itself:

$\Phi_{\gamma}=\{\gamma: \gamma \mid$ is nondecreasing and lower semi - continuous $\}$,

$\Phi_{\alpha}=\{\alpha: \alpha \mid$ is upper semi - continuous $\}$,

$\Phi_{\beta}=\{\beta: \beta \mid$ is lower semi - continuous $\}$,

Also by using Ansari's method, one can prove that the following Theorem genuinely generalizes recent results from (Karapinar \& Salimi, 2012) in several directions. Its proof is omitted.

Theorem 6 Let $(X, \preccurlyeq)$ be a partially ordered set and let there exist a metric $d$ on $X$ such that $(X, d)$ is a complete metric space and let $f: X \rightarrow X$ be a nondecreasing selfmap. Assume that there exist $\gamma \in \Phi_{\gamma}, \alpha \in \Phi_{\alpha}, \beta \in \Phi_{\beta}$ and $F \in \mathrm{C}$ such that for all $s, t \geq 0$,

$$
t>0 \text { and }(s=t \text { or } s=0) \text { implies } \gamma(t)-F(\alpha(s), \beta(s))>0 \text {, }
$$

and

$$
\gamma(d(f x, f y)) \leq F(\alpha(M(x, y)), \beta(M(x, y)))
$$

for all comparable $x, y \in X$, where

$$
M(x, y)=\max \left\{d(x, y), d(x, f x), d(y, f y), \frac{1}{2}(d(x, f y)+d(y, f x))\right\} .
$$

Suppose that, either

(i) $f$ is continuous, or

(ii) if a nondecreasing sequence $\left\{x_{n}\right\}$ converges to $x \in X$, then $x_{n} \preccurlyeq x$ for all $n \in N \cup\{0\}$.

If there exists $x_{0} \in X$ such that $x_{0} \preccurlyeq f x_{0}$, then $f$ has a fixed point. 


\section{References}

Abbas, M., \& Jungck, G. 2008. Common fixed point results for noncommuting mappings without continuity in cone metric spaces. Journal of Mathematical Analysis and Applications, 341(1), pp.416-420. Available at: http://dx.doi.org/10.1016/j.jmaa.2007.09.070.

Ansari, A.H. 2014a. Note on " $\alpha$ - admissible mappings and related fixed point theorems", pp.373-376. In: The 2nd Regional Conference on Mathematics And Applications, PNU, September.

Ansari, A.H. 2014b. Note on " $\varphi-\psi$ - contractive type mappings and related fixed point", pp.377-38. In: The 2nd Regional Conference on Mathematics And Applications, PNU, September.

Ansari, A.H., \& Chandok, S. 2016. Make unification on $\alpha$-admissible mappings and related fixed point theorems. Scientific Publications of the State University of Novi Pazar Series A: Applied Mathematics, Informatics and mechanics, 8(1), pp.65-71.

http://dx.doi.org/10.5937/spsunp1601065a.

Available at:

Ansari, A.H., Dolićanin-Djekić, D., Došenović, T., \& Radenović, S. 2017. Coupled coincidence point theorems for $(\alpha-\mu-\psi-H-F)$ two sided-contractive type mappings in partially ordered metric spaces using compatible mappings. Filomat, $\quad 31(9), \quad$ pp.2657-2673. Available at: http://journal.pmf.ni.ac.rs/filomat/index.php/filomat/article/view/3628/2113.

Altun, I., Damjanović, B., \& Djorić, D. 2010. Fixed point and common fixed point theorems on ordered cone metric spaces. Applied Mathematics Letters, 23(3), $\quad$ pp.310-316.

http://dx.doi.org/10.1016/j.aml.2009.09.016.

Available at:

Amini-Harandi, A., \& Emami, H. 2010. A fixed point theorem for contraction type maps in partially ordered metric spaces and application to ordinary differential equations. Nonlinear Analysis: Theory, Methods and Applications, 72(5), pp.2238-2242. Available at: http://dx.doi.org/10.1016/j.na.2009.10.023.

Banach, S. 1922. Sur les opérations dans les ensembles abstraits et leur application aux équations intégrales. Fundamenta Mathematicae, 3, pp.133-181. Available at: http://eudml.org/doc/213289.

Boyd, D.W., \& Wong, J.S.W. 1969. On nonlinear contractions. Proceedings of the American Mathematical Society, 20(2), pp.458-464. Available at: http://dx.doi.org/10.1090/s0002-9939-1969-0239559-9.

Đorić, D. 2009. Common fixed point for generalized $(\psi, \varphi)$ - weak contractions. Applied Mathematics Letters, 22(12), pp.1896-1990. Available at: https://doi.org/10.1016/j.aml.2009.08.001.

Geraghty, M.A. 1973. On contractive mappings. Proceedings of the American Mathematical Society, 40(2), pp.604-608. Available at: http://dx.doi.org/10.1090/s0002-9939-1973-0334176-5.

\section{7}


Harjani, J., \& Sadarangani, K. 2009. Fixed point theorems for weakly contractive mappings in partially ordered sets. Nonlinear Analysis: Theory, Methods and Applications, 71(7-8), pp.3403-3410. Available at: http://dx.doi.org/10.1016/j.na.2009.01.240.

Hussain, N., Karapinar, E., Salimi, P., \& Akbar, F. 2013. $\alpha$ - admissible mappings and related fixed point theorems. Journal of Inequalities and Applications, 2013(1), p.114. Available at: http://dx.doi.org/10.1186/1029-242x-2013-114.

Jachymski, J. 2011. Equivalent conditions for generalized contractions on (ordered) metric spaces. Nonlinear Analysis: Theory, Methods and Applications, 74(3), pp.768-774. Available at: http://dx.doi.org/10.1016/j.na.2010.09.025.

Jungck, G. 1976. Commuting Mappings and Fixed Points. The American Mathematical Monthly, 83(4), pp.261-263. Available at: http://dx.doi.org/10.2307/2318216.

Karapinar, E., \& Salimi, P. 2012. Fixed Point Theorems via Auxiliary Functions. Journal of Applied Mathematics, 2012, pp.1-9. Available at: http://dx.doi.org/10.1155/2012/792174.

Khan, M.S., Swaleh, M., \& Sessa, S. 1984. Fixed point theorems by altering distances between the points. Bulletin of the Australian Mathematical Society, 30(1) pp.1-9.

Available

at: http://dx.doi.org/10.1017/s0004972700001659.

Liu, Z., Zhang, X., Ume, J.S., \& Kang, S.M. 2015. Common fixed point theorems for four mappings satisfying $\psi$-weakly contractive conditions. Fixed Point Theory and Applications, 20(1). Available at: http://dx.doi.org/10.1186/s13663-015-0271-z.

Radenović, S., \& Kadelburg, Z. 2010. Generalized weak contractions in partially ordered metric spaces. Computers \& Mathematics with Applications, 60(6), pp.1776-1783.

http://dx.doi.org/10.1016/j.camwa.2010.07.008. Available

Radenović, S., Kadelburg, Z., Jandrlić, D., \& Jandrlić, A. 2012. Some results on weakly contractive maps. Bull. Iran. Math. Soc, 38(3), pp.625-645. Available at: http://bims.iranjournals.ir/article_229.html.

Rhoades, B.E. 1977. A comparison of various definitions of contractive mappings. Transactions of the American Mathematical Society, 226, pp.257290. Available at: http://dx.doi.org/10.1090/s0002-9947-1977-0433430-4.

Rhoades, B.E. 2001. Some theorems on weakly contractive maps. Nonlinear Analysis: Theory, Methods and Applications, 47(4), pp.26832693. Available at: http://dx.doi.org/10.1016/s0362-546x(01)00388-1.

Salimi, P., Latif, A., \& Hussain, N. 2013. Modified $\alpha-\psi$-contractive mappings with applications. Fixed Point Theory and Applications, 1, p.151. Available at: http://dx.doi.org/10.1186/1687-1812-2013-151.

Samet, B., Vetro, C., \& Vetro, P. 2012. Fixed point theorems for $\alpha-\psi$ contractive type mappings. Nonlinear Analysis: Theory, Methods and Applications, 75(4), pp.2154-2165. Available at: http://dx.doi.org/10.1016/j.na.2011.10.014. 
ПРИМЕНЕНИЕ МЕТОДА АНСАРИ В ОБОБЩЕНИИ РЯДА РЕЗУЛЬТАТОВ В РАМКАХ ТЕОРИИ НЕПОДВИЖНОЙ ТОЧКИ: ОБЗОР

Татьяна М. Дошенович ${ }^{a}$, Стоян Н. Раденович

а Университет в г. Нови-Сад, Технологический фракультет, г. Нови-Сад, Республика Сербия,

${ }^{\sigma}$ Белградский университет, Машиностроительный фракультет, г. Белград, Республика Сербия

ОБЛАСТЬ: математика

ВИД СТАТЬИ: оригинальная научная статья

ЯЗЫК СТАТЬИ: английский

Резюме:

Цель данной статьи заключается в намерении показать, насколько функция С-класса, введенная А. Х. Ансари, является мощным средством для обобщения многих важных результатов в теории неподвижной точки.

Ключевые слова: "С» класс фуннций, метрическое пространство, последовательность Коши, общая неподвижная точка, неподвижная точка.

ПРИМЕНА АНСАРИЈЕВОГ МЕТОДА У ГЕНЕРАЛИЗАЦИЈИ НЕКИХ РЕЗУЛТАТА ИЗ ТЕОРИЈЕ НЕПОКРЕТНЕ ТАЧКЕ (ПРЕГЛЕД)

Татјана М. Дошеновић ${ }^{a}$, Стојан Н. Раденовић ${ }^{б}$

а Универзитет у Новом Саду, Технолошки факултет,

Нови Сад, Република Србија,

${ }^{\sigma}$ Универзитет у Београду, Машински факултет, Београд, Република Србија

ОБЛАСТ: математика

ВРСТА ЧЛАНКА: оригинални научни чланак ЈЕЗИК ЧЛАНКА: енглескИ

Сажетак:

Циљ овог рада јесте да се покаже да је С класа ффункција која је уведена у раду А. Х. Ансарија моћно средство у генерализацији многих важних резултата у теорији непокретне тачке.

Кључне речи: С класа функција, метрички простор, Кошијев низ, заједничка непокретна тачка, непокретна тачка. 
Paper received on / Дата получения работы / Датум пријема чланка: 01.12.2017. Manuscript corrections submitted on / Дата получения исправленной версии работы / Датум достављања исправки рукописа: 17.12.2017.

Paper accepted for publishing on / Дата окончательного согласования работы / Датум коначног прихватања чланка за објављивање: 18.12.2017.

(C) 2018 The Authors. Published by Vojnotehnički glasnik / Military Technical Courier (www.vtg.mod.gov.rs, втг.мо.упр.срб). This article is an open access article distributed under the terms and conditions of the Creative Commons Attribution license (http://creativecommons.org/licenses/by/3.0/rs/).

(c) 2018 Авторы. Опубликовано в «Военно-технический вестник / Vojnotehnički glasnik / Military Technical Courier» (www.vtg.mod.gov.rs, втг.мо.упр.срб). Данная статья в открытом доступе и распространяется в соответствии с лицензией «Creative Commons» (http://creativecommons.org/licenses/by/3.0/rs/).

(C) 2018 Аутори. Објавио Војнотехнички гласник / Vojnotehnički glasnik / Military Technical Courier (www.vtg.mod.gov.rs, втг.мо.упр.срб). Ово је чланак отвореног приступа и дистрибуира се у складу са Creative Commons licencom (http://creativecommons.org/licenses/by/3.0/rs/). 